\title{
Anticancer Activity and Nutritional Value of Extracts of the Seed of Glinus lotoides
}

\author{
Abebe Endale Mengesha and Bi-Botti C. YouAN* \\ Laboratory of Future Nanomedicines and Theoretical Chronopharmaceutics, Division of \\ Pharmaceutical Sciences, University of Missouri-Kansas City, 2464 Charlotte, \\ Kansas City, MO 64108, USA
}

(Received April 2, 2010)

\begin{abstract}
Summary The purpose of this study is to determine the anticancer activity and the nutritional values of the seeds of Glinus lotoides, a plant used as a dietary vegetable and medicinal plant in Asia and Africa. To achieve this goal, the seeds were extracted in soxhlet using solvents, namely $n$-hexane, dichloromethane, methanol and water. The methanol and $n$-hexane extracts showed differential growth inhibitory responses in carcinoma cell lines (Calu-3 $\mathrm{IC}_{50}=29.7$ and $79.8 \mu \mathrm{g} / \mathrm{mL}$ and Caco-2 $\mathrm{IC}_{50}=69.7$ and $74.6 \mu \mathrm{g} / \mathrm{mL}$, respectively) as compared to normal cell lines $\left(\mathrm{MDCK}_{\mathrm{IC}} \mathrm{C}_{50}=106.1\right.$ and $131.1 \mu \mathrm{g} / \mathrm{mL}$ and IEC- $6 \mathrm{IC}_{50}=134.0$ and $128.5 \mu \mathrm{g} / \mathrm{mL}$, respectively). In addition, these extracts induced significant apoptosis in the cancer cells $(p<0.05)$ at $100 \mu \mathrm{g} / \mathrm{mL}$. The seeds of $G$. lotoides were found to contain nutritional compounds of well-established chemopreventive activity, including vitamin E, folic acid, selenium and calcium. The hydrophilic oxygen radical absorption capacity (ORAC) value was found to be $123 \mu \mathrm{M}$ Trolox Equiv./g, indicating the antioxidant activity of the plant. These data suggest that the seeds of G. lotoides could potentially be used in the diet in chemoprevention of cancer and warrant further confirmatory preclinical and clinical studies. The amount of protein, carbohydrate, fat, ash, moisture, sugar profile and fatty acids further support the nutritional value of the seeds.
\end{abstract}

Key Words Africa, Glinus lotoides, traditional medicine, chemoprevention, nutritional values

On 31 August 2007, the Ministers of Health of the WHO African Region, assembled in Brazzaville for the fifty-seventh session of the Regional Committee for Africa (1), made five commitments including the need to intensify efforts to produce inventories of effective practices as well as evidence of the safety, efficacy and quality of traditional medicines and undertake relevant research. In fact, due to a lack of sufficient local expertise and resources, the potential therapeutic value, safety and efficacy of many African medicinal plants are still unelucidated. However, several early reports underscored the importance of traditional medicine (24). For example mineralogical analyses demonstrated a striking similarity between the Uzalla village antidiarrheal clay (in Nigeria) and the clay in the commercial pharmaceutical Kaopectate (2). It has been shown that traditional and modern medicine can merge to save lives (5), and recently Indonesia tapped into village wisdom to fight bird flu (6). AIDS in Africa has also raised the question of trust (7) and recognition (8) of traditional healers. It is critical to know the nutritional value of African diets for improved disease prevention and management. For example, iron overload in Africa may be caused by an interaction between the amount of dietary iron and a gene distinct from any HLA-linked

\footnotetext{
*To whom correspondence should be addressed.

E-mail: youanb@umkc.edu
}

gene (9). We have previously reported on the efficacy of some African plants indicated for Trypanosoma brucei treatment (10). To further contribute to this bridging of the knowledge gap in this area of research, here we focus our effort on Glinus lotoides.

G. lotoides L. (Molluginaceae) is one such promising dietary vegetable and medicinal plant in Africa and Asia, the seeds of which are traditionally used as an antitumor, antifungal and anthelminthic treatment $(11,12)$. The taenicidal activities against Tenia saginata and Hymenolepis nana worms $(13,14)$, and the antitumor activities against Dalton's ascitic lymphoma in Swiss albino mice (11) have been evaluated. The pharmacological activities of the plant have been attributed to its saponins and flavonoids (11-14). Phytochemical investigation of G. lotoides afforded several hopane triterpenoidal saponins (glinusides A-I, lotoideside A-F and succulentoside B), flavonoids (vicenin-2, vitexin$2^{\prime \prime}$-O-glucoside, apigenin-7-O-glucoside, isovitexin, and luteolin-7-O-glucoside) and isoflavonoids $(15,16)$.

Epidemiological evidence suggests that micronutrients in the diet prevent neoplastic transformation of normal cells or slow the progression of established malignant changes in cancer cells (17). Based on this association between diet and prevention of cancer, edible plants are increasingly being studied as potential sources of new anticancer agents $(18,19)$. Micronutrients such as antioxidant vitamins and minerals as well 
as certain phytochemicals present in vegetables and fruits are regarded as the most desirable class of chemopreventive agents (20). The protective effects against carcinogenesis may derive from each component acting via a variety of distinct and potentially interactive mechanisms (21). Additionally, the extended duration in the conversion of adenoma to adenocarcinoma provides a window of opportunity for dietary intervention (22).

Despite the popularity of the seed of G. lotoides in Asia and Africa, there are no systematic studies elucidating the macronutrient and micronutrient contents of the seeds of G. lotoides or the chemoprevention activity, making it difficult to scientifically support its extensive utilization as an alternative chemopreventive agent or food in the future. This study was designed to bridge the knowledge gap by evaluating the antiproliferative activities on mammalian cell lines. We have also examined and reported, for the first time, the macro- and micronutrient values of the seeds of G. lotoides.

\section{MATERIALS AND METHODS}

Plant material and extraction. Fruits of G. lotoides were purchased from the local market, 'Merkato' in Addis Ababa, Ethiopia. The identity was confirmed by the National Herbarium, Department of Biology, Faculty of Science, Addis Ababa University, Ethiopia (voucher specimen No. 003444). The seeds (500 g) were separated from the fruits, powdered using a mortar and pestle and extracted successively with $500 \mathrm{~mL}$ each of $n$-hexane, dichloromethane, methanol and water in soxhlet extraction set up for $2 \mathrm{~h}$ each. The extracts were collected, concentrated in a Rotavapor (Buchi Labortechnik AG, Flavil, Switzerland) at reduced pressure and dried using a Freeze Dryer (Labconco, Co., Kansas City, MO). They were stored at room temperature before subsequent experiments.

Cell culture. Caco-2, Calu-3, MDCK and IEC-6 were obtained from American Type Culture Collection (ATCC, Manassas, VA, USA). Cell culture medium and fetal bovine serum were purchased from Invitrogen, Co. (Carlsbad, CA). Cell culture plasticware was obtained from Invitrogen, Fisher Scientific (Hanoverpark, IL) and VWR International (Chicago, IL). Cells were maintained in Dulbecco's Modified Eagle's Medium (DMEM), supplemented with $10 \%$ fetal bovine serum, penicillin (100 units/mL), and streptomycin $(100 \mu \mathrm{g} / \mathrm{mL})$. Cells were incubated at $37^{\circ} \mathrm{C}$ in a fully humidified environment under $5 \% \mathrm{CO}_{2}$. Caco-2, Calu-3 and MDCK cells at passage 30-40 and IEC-6 cells at passage 5-15 were used for the experiments. Cells were subcultured before reaching 90\% confluency in 2-3 d interval.

In vitro assays of antiproliferative activity. The inhibitory effects of the extracts of G. lotoides on cell growth were determined by the analysis of viable cells using 3(4,5-dimethylthiazol-2-yl)-2,5-diphenyltetrazolium bromide (MTT) assay following the manufacturer's protocol. Cells were seeded in 96-well plates $\left(1 \times 10^{4}\right.$ cells/ well), each well containing $100 \mu \mathrm{L}$ of fresh medium. The cells were cultured for $24 \mathrm{~h}$ and the extracts of $G$. lotoides were then added to the wells in doses of 10,50 , 100 and $250 \mu \mathrm{g} / \mathrm{mL}$. DMSO (Sigma, St. Louis, MO) at a concentration of $0.5 \%$ was used to improve the solubility of the extracts in the culture medium. After $24 \mathrm{~h}$ of treatment, the cells were treated with $15 \mu \mathrm{L}$ of MTT (Promega, Madison, WI) and were incubated for another $4 \mathrm{~h}$. The medium was aspirated and replaced with DMSO, and the plate was agitated. The plate was read on a microplate reader (Beckman Coulter, Multimode detector, Fullerton, CA) at $570 \mathrm{~nm}$. The vehicle-treated cells, which did not receive extract treatment, were used as a control for $100 \%$ cell viability. Concentrations of extract that inhibited proliferation of cultured cells by $50 \%$ ( $\mathrm{IC}_{50}$ values) were determined from log-transformed data using Graphpad ${ }^{\circledR}$ Prism 5 software.

Caspase-3/7 activity assay. This study was performed using the APO-ONE ${ }^{\circledR}$ homogeneous Caspase-3/ 7 assay kit (Promega, G7790) following the manufacturer's protocol. Cultures were prepared and exposed to the extracts of G. lotoides as described above. No cells were seeded in the blank control wells. In the negative control, $0.5 \%$ DMSO in culture medium was used. After incubating cells at $37^{\circ} \mathrm{C}$ with $5 \% \mathrm{CO}_{2}$ for $24 \mathrm{~h}$, the caspase substrate was added to each well, and the plate was incubated at room temperature. The level of fluorescence was read at $24 \mathrm{~h}$ using a microplate reader (Beckman Coulter) with excitation at $485 \mathrm{~nm}$ and emission at $535 \mathrm{~nm}$.

Morphological changes. The morphological changes of Caco-2, Calu-3, MDCK and IEC-6 cells treated with $100 \mu \mathrm{g} / \mathrm{mL}$ of the extracts of G. lotoides for 24 and $48 \mathrm{~h}$ were observed by using an inverted optical microscope (VistaVision, VWR, USA) at magnifications of 100, 250 and 400 times.

Nutritional content analyses. Compositional analyses of the powdered seeds of G. lotoides were conducted to measure proximate package analysis (protein, total carbohydrate, ash, moisture and fat), sugar profile, fatty acids $\left(\mathrm{C}_{8}-\mathrm{C}_{22}\right)$, vitamins (natural vit. $\mathrm{E}(23)$, niacin, thiamin and folic acid), secondary metabolites (campesterol, stigmasterol, $\beta$-sitiosterol and other sterols/ stanols) and minerals (calcium, iron, magnesium, phosphorus, potassium, selenium and sodium). All compositional analyses were performed at Covance Laboratories, Inc. (Madison, WI) as described in Official Methods of Analysis ${ }^{\mathrm{TM}}$ (OMA) (24) of The Association of Analytical Communities (AOAC International).

Oxygen radical absorption capacity (ORAC). The ORAC assay was also performed by Covance Laboratories according to a previously described method (25) using the antioxidant, 6-hydroxy-2,5,7,8-tetramethylchroman-2-carboxylic acid or trolox (a vitamin E analogue) as standard.

Statistical analysis. Data were converted to percent control by dividing raw values of each replicate by the mean control values (separate means were calculated for controls from each time period, when applicable). The ratios were then multiplied by 100 . Results were analyzed using ANOVA and Bonferroni's multiple comparison test to assess statistical significance. Values of 

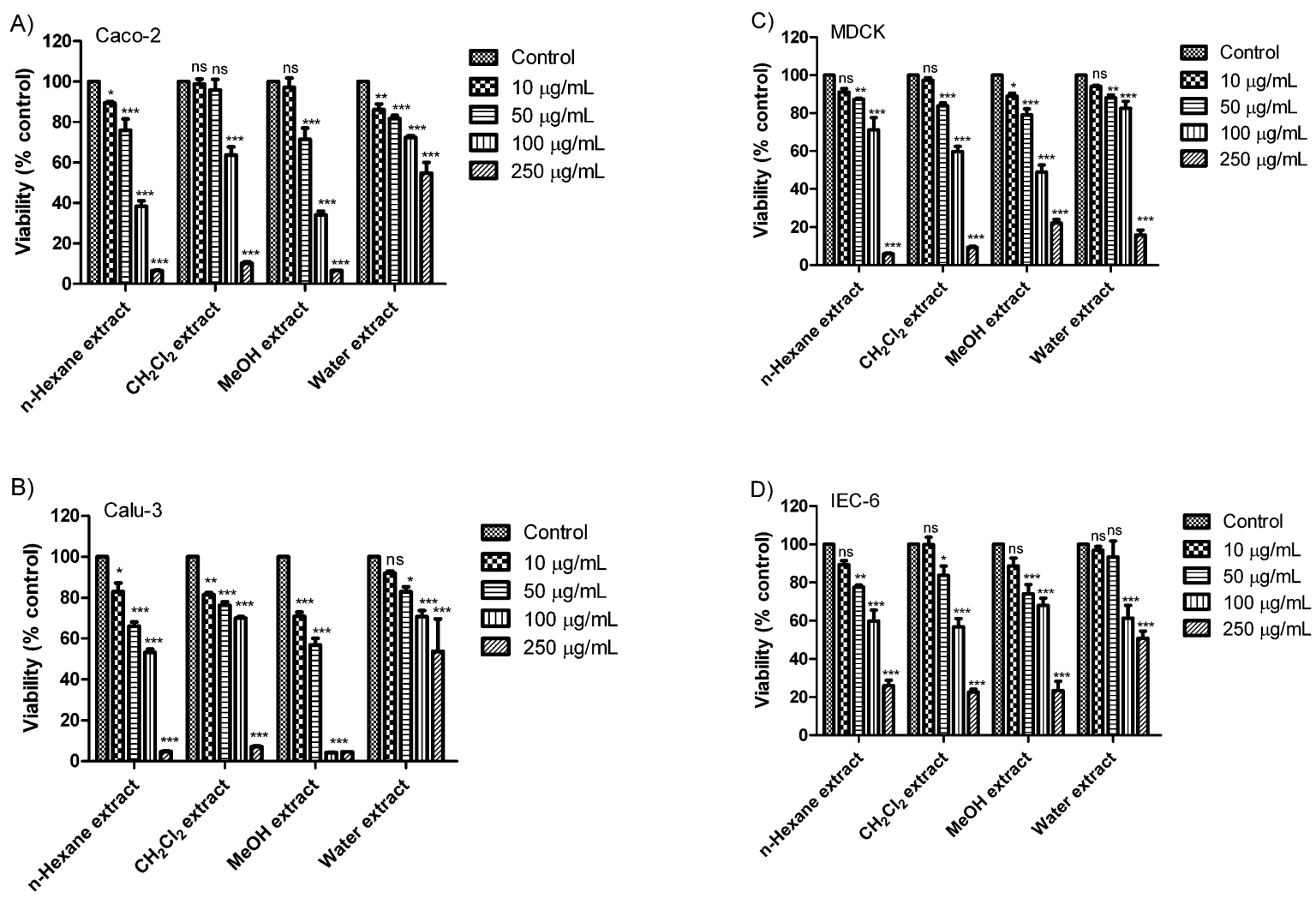

Fig. 1. Viability of the (A) Caco-2, (B) Calu-3, (C) MDCK and (D) IEC-6 cell lines following treatment by four extracts of G. lotoides. The cells were incubated with the extracts $(0,10,50,100$ and $250 \mu \mathrm{g} / \mathrm{mL})$ for $24 \mathrm{~h}$ and the percent viability was measured using MTT assay. Vehicle-treated cells are referred to as $100 \%$ viable. Data shown are mean values \pm SE determined from six independent experiments. ${ }^{* * *} p<0.001,{ }^{* *} p<0.01,{ }^{*} p<0.05$ and ns $p>0.05$ compared to the control.

Table 1. Antiproliferative activity of the extracts of the seeds of Glinus lotoides against two carcinoma and two normal cell lines ${ }^{1}(n=6)$.

\begin{tabular}{lrcrc}
\hline \multirow{2}{*}{ Cells } & \multicolumn{3}{c}{ IC $_{50}$ value $(\mu \mathrm{g} / \mathrm{mL})$} \\
\cline { 2 - 5 } & $n$-Hexane extract & Dichloromethane extract & Methanol extract & Water extract \\
\hline Caco2 & $74.6 \pm 1.20$ & $140.3 \pm 1.32$ & $69.7 \pm 1.21$ & $268.4 \pm 1.13$ \\
Calu-3 & $79.8 \pm 1.26$ & $112.0 \pm 1.27$ & $29.7 \pm 1.27$ & $262.2 \pm 1.23$ \\
MDCK & $131.1 \pm 1.32$ & $116.0 \pm 1.24$ & $106.1 \pm 1.13$ & $174.8 \pm 1.31$ \\
IEC-6 & $128.5 \pm 1.12$ & $131.8 \pm 1.17$ & $134.0 \pm 1.17$ & $242.0 \pm 1.20$ \\
\hline
\end{tabular}

${ }^{1}$ Values are means \pm SE.

$p<0.05$ were considered statistically significant.

\section{RESULTS AND DISCUSSION}

The rationale for the selection of G. lotoides for evaluation of its anticancer activity is threefold. (i) It has been used widely for many years as a traditional folk medicine, and it has been shown to exert effects on various human illnesses $(11,12)$. (ii) It is used as a dietary vegetable, indicating possible safety in its future utilization. (iii) It contains several classes of plant flavonoids and saponins which have been suggested to have preventive roles in cancer $(15,16)$.

The cell lines were selected to represent the traditionally exposed mammalian cells (cancerous and normal cell lines of the gastrointestinal tract, kidney cells). In addition, Calu-3 was selected in order to investigate possible anticancer activity of the plant on lung cancer.

The extracts of the seeds of G. lotoides inhibited proliferation of the cancer cell lines in a dose-dependent manner (Fig. 1), with $\mathrm{IC}_{50}$ values as low as $29.7 \mu \mathrm{g} / \mathrm{mL}$ for the methanol extract on Calu-3 cell lines (Table 1). The extracts were more effective in inhibiting growth of cancer cells (Figs. 1A and $\mathrm{B}$ ) than that of normal immortalized cell lines (Figs. $1 \mathrm{C}$ and $\mathrm{D}$ ). The $\mathrm{IC}_{50}$ values on normal cell lines are relatively higher $(>106 \mu \mathrm{g} /$ $\mathrm{mL}$ ) as compared with the values for carcinoma cell lines. The water extract showed the least antiproliferative activity. This could be attributed in part to the nature of the soxhelt extraction in that most of the active ingredients could have been extracted with the solvents used in earlier extraction steps. In this study, the $n$-hexane extract showed significant antiprolifera- 
A)

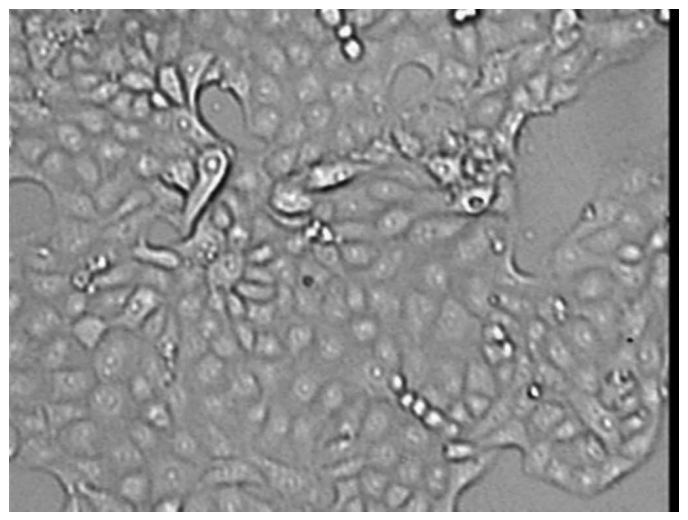

B)

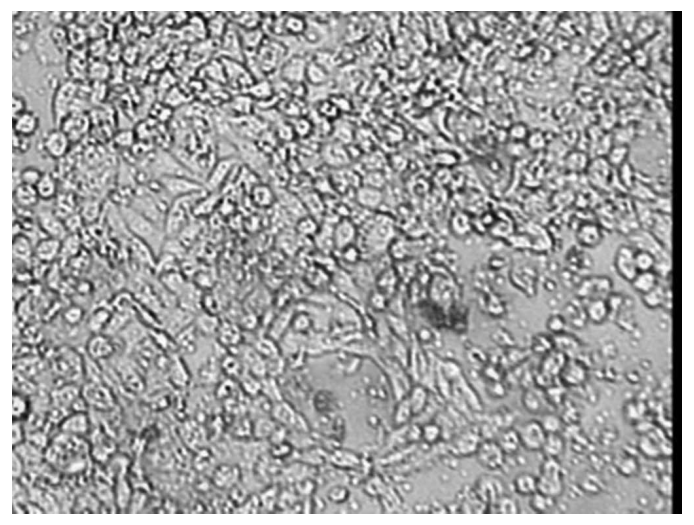

C)

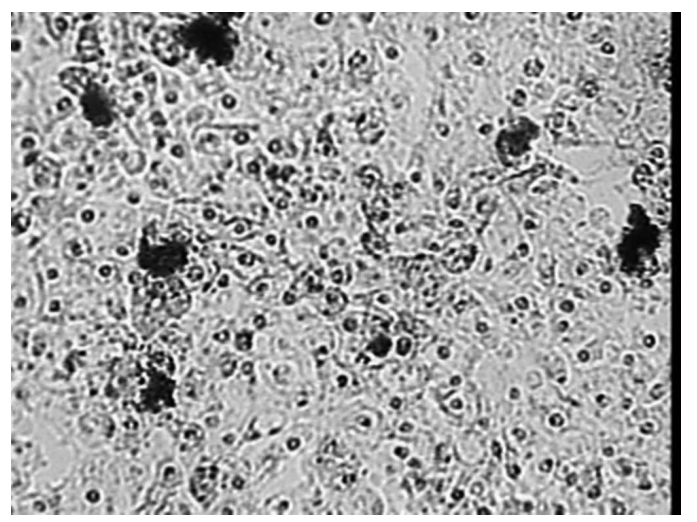

D)

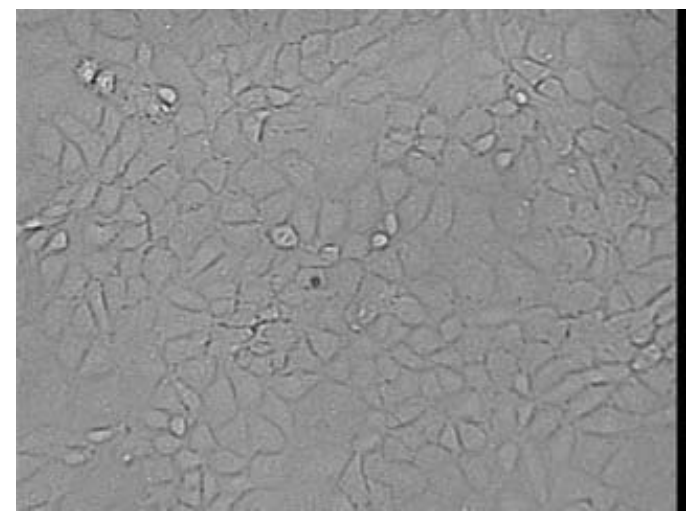

E)

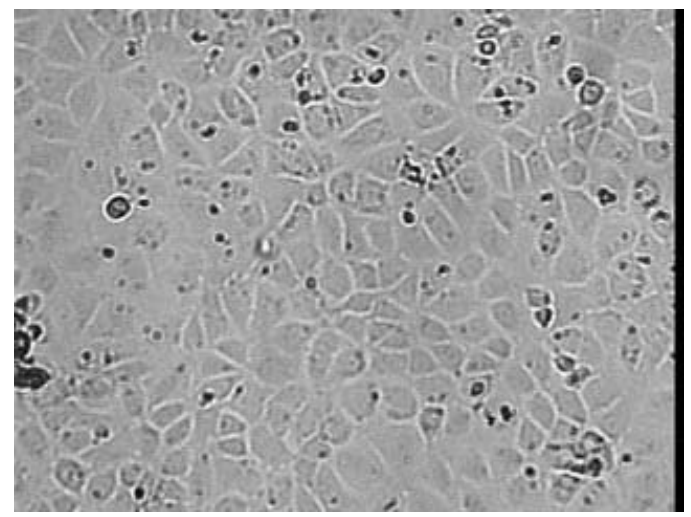

F)

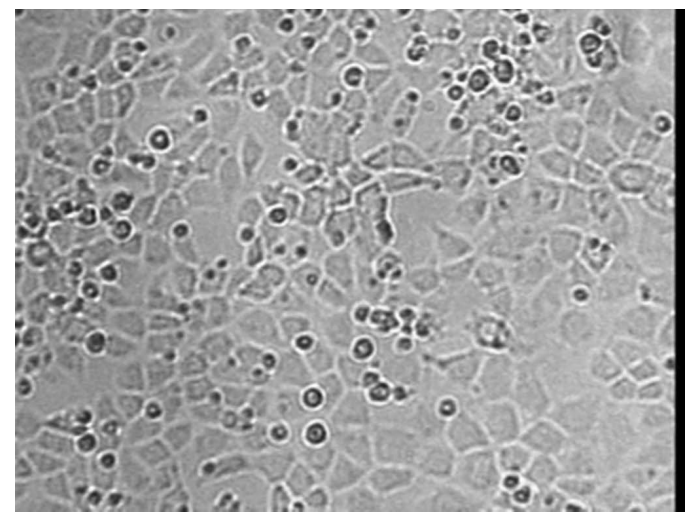

Fig. 2. Morphological changes of cells treated with $100 \mu \mathrm{g} / \mathrm{mL}$ of methanol extract of G. lotoides. Optical microscope images of (A) Caco-2 cells without extract, (B) Caco-2 cells treated with the extract for $24 \mathrm{~h}$, (C) Caco-2 cells treated with the extract for $48 \mathrm{~h}$, (D) IEC-6 cells without extract, (E) IEC-6 cells treated with the extract for $24 \mathrm{~h}$, (F) IEC-6 cells treated with the extract for $48 \mathrm{~h}$.

tive activity against Caco-2 $\left(\mathrm{IC}_{50}=74.6 \mu \mathrm{g} / \mathrm{mL}\right)$ and Calu-3 $\left(\mathrm{IC}_{50}=79.8 \mu \mathrm{g} / \mathrm{mL}\right)$. Previous phytochemical and bioactivity studies focused more on the polar components of the plant $(11,16)$ in comparison to the nonpolar components. Results of this study suggested that the non-polar components of the plant need to be investigated to elucidate their mechanism of action.

The morphological changes of the cells (Fig. 2) as well as the significant elevation of the levels of caspase-
3/7 (Fig. 3) in cells treated with the extract of the plant strongly suggested that the mechanism of cell death could be apoptosis (26). However in future studies, the use of techniques such as DNA fluorescence will allow us to definitely confirm this observation.

During live cell imaging, we noticed changes in cell morphology consistent with an apoptotic mechanism of cell death. As a representative, Fig. 2 depicts the morphological changes of Caco-2 (Figs. 2A-C) and IEC-6 

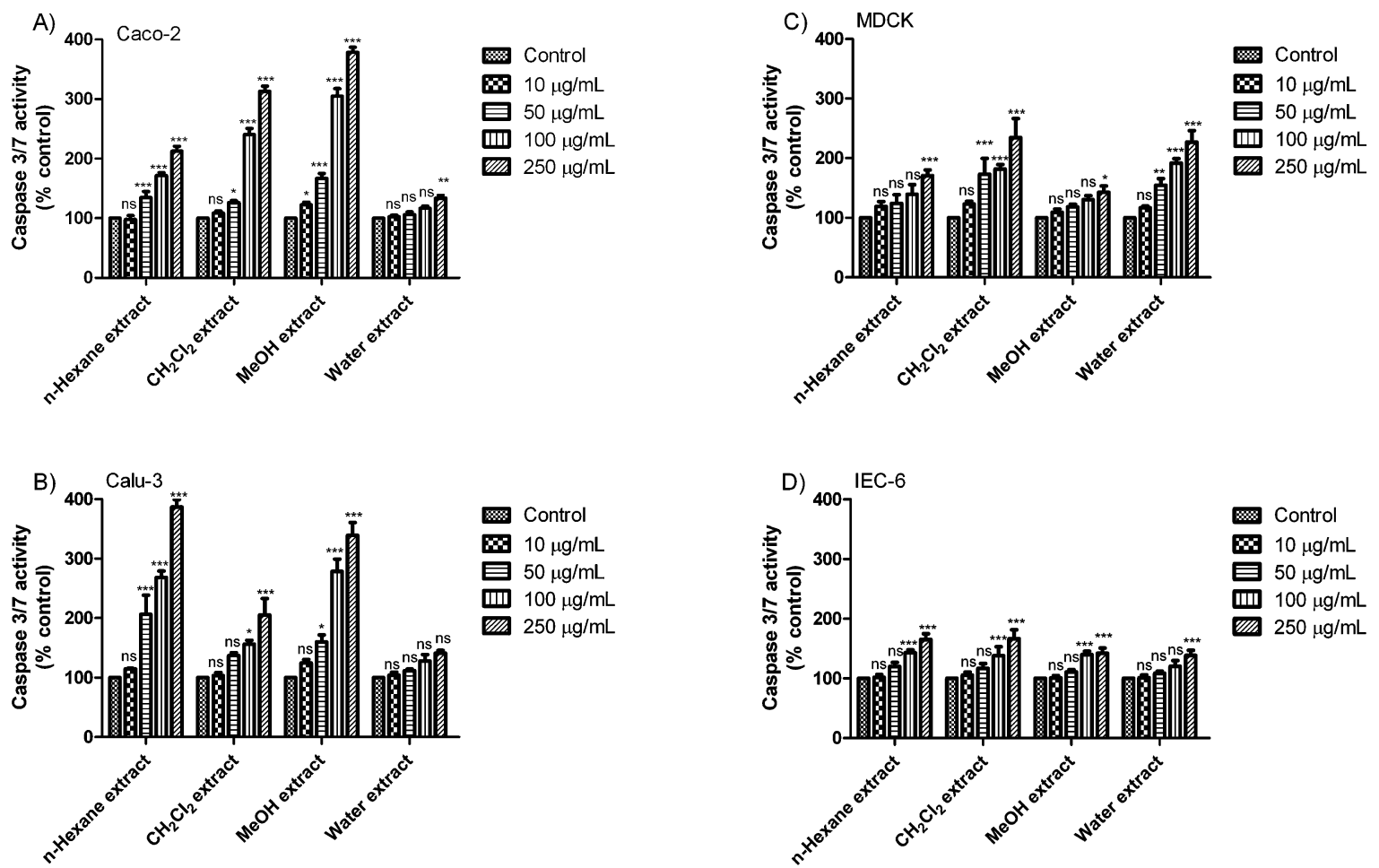

Fig. 3. Caspase-3/7 activation of (A) Caco2, (B) Calu-3, (C) MDCK and (D) IEC-6 cell lines following treatment with four extracts of G. lotoides. The cells were treated with extracts at various concentrations $(0,10,50,100$ and $250 \mu \mathrm{g} / \mathrm{mL})$ for $24 \mathrm{~h}$. Data shown are mean values \pm SE determined from six independent experiments. ${ }^{* * *} p<0.001,{ }^{* *} p<0.01,{ }^{*} p<0.05$ and ns $p>0.05$ compared to the control.

(Figs. 2D-F) cells upon exposure to the methanol extract of the seeds of the plant at a concentration of $100 \mu \mathrm{g} / \mathrm{mL}$. As shown in this figure, cancer cells treated with the extract show features of cell shrinkage, irregularity in shape and cellular detachment. These changes significantly increased from 24 to $48 \mathrm{~h}$, suggesting a time-dependent effect of the extract. The morphological changes were more significant on the cancer cells. Figures 2D-F show the morphological changes of IEC-6 cells exposed to the same extract. The results obtained from the optical images are in a good agreement with the MTT assay results (Fig. 1), where Caco-2 cells showed less than $40 \%$ viability when exposed to $100 \mu \mathrm{g} / \mathrm{mL}$ methanol extract. On the other hand, IEC-6 cells showed $75 \%$ viability under the same condition.

Caspase-3/7 assay (Figs. 3A-D) that specifically identifies whether effector caspases 3 and 7 are activated, could confirm that cell death occurred via apoptosis. As shown in Fig. 3A, the methanol extract showed the highest caspase activation in Caco- 2 cells. At concentration of $250 \mu \mathrm{g} / \mathrm{mL}$, the methanol extract had increased the caspase activity ( 4 times) compared to the control. In Calu-3 cells, $n$-hexane extract showed the maximum induction of apoptosis. The methanol extract also showed a considerable increase in caspase activity, whereas the water extract was statistically insignificant $(p>0.05)$ at all concentrations tested on Calu-3 cell lines.

Epidemiological evidence suggests that plant-based dietary agents decrease the risk of some types of human cancer. Intake of $400-600 \mathrm{~g} / \mathrm{d}$ of fruits and vegetables is
Table 2. Vitamin and mineral composition of the seeds of Glinus lotoides.

\begin{tabular}{lr}
\hline \multicolumn{1}{c}{ Vitamins and minerals } & \multicolumn{1}{c}{ Amount } \\
\hline Vitamin E (natural) & $12.0 \mathrm{IU} / 100 \mathrm{~g}$ \\
Thiamin & $0.36 \mathrm{mg} / 100 \mathrm{~g}$ \\
Folic acid & $0.108 \mathrm{mg} / 100 \mathrm{~g}$ \\
Niacin & $4.90 \mathrm{mg} / 100 \mathrm{~g}$ \\
Calcium & $368.0 \mathrm{mg} / 100 \mathrm{~g}$ \\
Iron & $607.0 \mathrm{mg} / 100 \mathrm{~g}$ \\
Magnesium & $401.0 \mathrm{mg} / 100 \mathrm{~g}$ \\
Phosphorus & $456.0 \mathrm{mg} / 100 \mathrm{~g}$ \\
Potassium & $170.0 \mathrm{mg} / 100 \mathrm{~g}$ \\
Selenium & $0.0858 \mathrm{mg} / 100 \mathrm{~g}$ \\
Sodium & $101.0 \mathrm{mg} / 100 \mathrm{~g}$ \\
\hline
\end{tabular}

associated with reduced risk of several cancers (27). Micronutrients (antioxidant vitamins and trace minerals) as well as certain phenolic compounds present in vegetables and fruits are regarded as the most desirable class of chemopreventive agents $(20,27,28)$.

As shown in Tables 2-5, the seeds of G. lotoides were found to contain macro- and micronutrients of wellestablished chemopreventive activity. The seeds contain a high concentration of vit. E (12.0 IU/100 g). The protective effect of vit. E-containing foods in colon and rectal cancer has been reported (17). Vit. E functions as the major lipid soluble antioxidant in cell membranes; it is a chain-breaking free-radical scavenger and specifically inhibits lipid peroxidation, a biological activity rel- 
Table 3. Fatty acid profile of the seeds of Glinus lotoides with trans fat analyzed by GC.

\begin{tabular}{llrr}
\hline & & \multicolumn{2}{c}{ Amount } \\
\cline { 3 - 4 } Fatty acid composition & & $\mathrm{g} / 100 \mathrm{~g}^{1}$ & \multicolumn{1}{c}{$\%^{2}$} \\
\hline Capric acid & $10: 0$ & 0.010 & 0.06 \\
Lauric acid & $12: 0$ & 0.031 & 0.20 \\
Myristic acid & $14: 0$ & 0.112 & 0.72 \\
Pentadecanoic acid & $15: 0$ & 0.010 & 0.06 \\
Palmitic acid & $16: 0$ & 2.60 & 16.67 \\
Palmitoleic acid & $16: 1$ & 0.024 & 0.15 \\
Heptadecanoic acid & $17: 0$ & 0.016 & 0.10 \\
Stearic acid & $18: 0$ & 0.688 & 4.41 \\
Oleic acid & $18: 1$ & 6.820 & 43.72 \\
Linoleic acid & $18: 2(\omega-6)$ & 4.570 & 29.29 \\
$\alpha$-Linolenic acid & $18: 3(\omega-3)$ & 0.375 & 2.40 \\
Arachidic acid & $20: 0$ & 0.057 & 0.37 \\
Eicosenoic acid & $20: 1$ & 0.032 & 0.21 \\
Arachidonic acid & $20: 4(\omega-6)$ & 0.014 & 0.09 \\
Behenic acid & $22: 0$ & 0.078 & 0.50 \\
Lignoceric acid & $24: 0$ & 0.033 & 0.21 \\
Docosahexaenoic acid & $22: 6(\omega-3)$ & 0.010 & 0.06 \\
Others & & 0.120 & 0.77 \\
Total fatty acid & & 15.6 & 100 \\
& & & \\
\hline 1 & &
\end{tabular}

${ }^{1}$ Measured from $100 \mathrm{~g}$ of seeds.

${ }^{2}$ Calculated from total fatty acid content.

evant to carcinogen-induced DNA damage. The mechanisms through which tocopherols inhibit cell proliferation include inhibition of protein kinase C activity, induction of NADPH detoxification enzyme, and reduction of arachidonic acid and prostaglandin metabolism (29).

Folic acid in concentration of $108 \mu \mathrm{g} / 100 \mathrm{~g}$ was found in the seeds of G. lotoides (Table 2). Folic acid is essential for the biosynthesis of purines and thymidylate, and is an important mediator in the transfer of methyl groups for DNA methylation. Folate insufficiency has been implicated in the development of several human and experimental cancers (30).

Selenium and calcium are minerals that appear to play important roles in the chemoprevention of cancer (31). As shown in Table 2, together with other minerals, the seeds of G. lotoides were found to contain selenium $(85.8 \mu \mathrm{g} / 100 \mathrm{~g})$ and calcium $(368 \mathrm{mg} / 100 \mathrm{~g})$. Selenium is one of the few micronutrients for which an anticarcinogenic effect has for long been postulated and finally demonstrated in a large controlled clinical trial (32). Recommended intake and upper tolerable level are $40-55$ and $300 \mu \mathrm{g} / \mathrm{d}$ (33), indicating the need to control the amount ingested during its traditional use as well as dietary consumption. Induction of apoptosis is considered an important cellular event that can account for the cancer preventive effects of Se (34). Hence, a better chemical characterization of Se compounds in the seeds of G. lotoides is needed to elucidate the cancer prevention activity of the plant. Additionally, the high potassium content of the seeds $(1,170 \mathrm{mg} /$ $100 \mathrm{~g}$ ) (Table 2) might be beneficial for cardiovascular
Table 4. Assay of the fatty acid composition of the seeds of Glinus lotoides with respect to saturation.

\begin{tabular}{ll}
\hline & Amount $(\mathrm{g} / 100 \mathrm{~g})$ \\
\hline Saturated fat & 3.47 \\
$\omega-3$ & 0.385 \\
$\omega-6$ & 4.58 \\
Total trans fatty acids & 0.149 \\
Monounsaturated fat & 6.58 \\
Polyunsaturated fat & 4.75 \\
\hline
\end{tabular}

Table 5. Macro-nutritional values of the seeds of Glinus lotoides.

\begin{tabular}{lr}
\hline & \multicolumn{1}{c}{ Amount } \\
\hline Protein $^{1}$ & $20.4 \mathrm{~g} / 100 \mathrm{~g}$ \\
Total carbohydrate $^{2}$ Total sugar $^{2}$ & $47.0 \mathrm{~g} / 100 \mathrm{~g}$ \\
Moisture $^{3}$ & $1.0 \mathrm{~g} / 100 \mathrm{~g}$ \\
Ash & $6.7 \mathrm{~g} / 100 \mathrm{~g}$ \\
Calories & $10.3 \mathrm{~g} / 100 \mathrm{~g}$ \\
Calories from fat & $410 \mathrm{cal} / 100 \mathrm{~g}$ \\
Cholesterol & $140 \mathrm{cal} / 100 \mathrm{~g}$ \\
& $<0.1 \mathrm{mg} / 100 \mathrm{~g}$ \\
\hline
\end{tabular}

\footnotetext{
${ }^{1}$ (Nx6.25) Dumas method.

${ }^{2}$ Sugar profile: fructose $(0.2 \mathrm{~g})$, glucose $(0.3 \mathrm{~g})$, sucrose (0.5 g) per $100 \mathrm{~g}$ seed.

${ }^{3} 100$ degree vacuum oven.
}

health. More research is needed to assess the levels of other phytochemicals present in the seeds of G. lotoides to support dietary recommendations or health claims.

Tables 3 and 4 depict the fatty acid profile of the seeds of G. lotoides. The seeds of the G. lotoides contain a high concentration of $\omega$-3 fatty acid $(\alpha$-linolenic acid, $375 \mathrm{mg} / 100 \mathrm{~g}$ of seeds). It has been reported that fats containing $\omega$-3 fatty acids reduced chemically induced colon tumor (35). It was also reported that $\omega$-3 fatty acids present in dietary meal inhibit oxidative metabolism of arachidonic acid by the cyclooxygenase (COX) pathway responsible for prostaglandin synthesis (36). Studies have indicated that prostaglandin synthesis inhibitors prevent colon carcinogenesis (37). Recently Suzuki et al. showed that consumption of Catalpa ovata seed oil, which is rich in conjugated linolenic acid, suppresses the development of colonic aberrant crypt foci induced by azoxymethane in rats (35). Phytosterols were reported to show significant cancer prevention activity (38). Table 5 shows the macro-nutritional values of the seeds of G. lotoides. The seeds of G. lotoides were found to contain a total of $124.29 \mu \mathrm{M}$ Trolox Equiv./g ORAC activity with predominantly hydrophilic ORAC $(123 \mu \mathrm{M})$ and lipophilic ORAC $(1.29 \mu \mathrm{M})$. There is overwhelming evidence that reactive oxygen species (ROS) are the underlying cause of many chronic diseases that involve enhanced intracellular oxidative stress. At elevated levels, ROS have been reported to alter the structure of cell membranes, which can adversely affect cell function and potentially lead to cell 
damage and cell death (39).

The seeds of G. lotoides have been reported to contain a high concentration of flavonoids, commonly known as apigenin and its glycosides (40). The dietary flavonoids possess antioxidative, anti-inflammatory, and possibly anticarcinogenic properties and are receiving increasing attention. Flavonoids have been demonstrated to induce cell death or cell cycle arrest depending on their type and concentration (18). Apigenin, a widely distributed plant flavonoid abundantly present in fruits and vegetables, is a free-radical scavenger that has been shown to possess anti-inflammatory and anticarcinogenic effects (41). Moreover, rooibos (Aspalathus linearis) and honeybush (Cyclopia intermedia), two popular tisanes in South Africa that are rich in polyphenols, have demonstrated potent antioxidant, immune-modulating and chemopreventive actions in experimental animal studies (42). These data suggest that the seed of $G$. lotoides may have potential chemopreventive activities as well.

\section{CONCLUSION}

The extracts of the seeds of G. lotoides (a seed used as a food and in African traditional medicine) inhibited selectively the growth of cancer cells in vitro in a concentration-dependent manner. The micronutrient and the chemical profile of these seeds are reported here for the first time and the documented effect of the seeds was consistent with that observed in vitro bioactivity. Like Moringa oleifera (43), the seeds of G. lotoides appear to be a food plant with multiple potential medicinal uses. These data suggest that these seeds could potentially be used as a food in the chemoprevention of cancer and warrant further confirmatory preclinical and clinical studies including detailed content analysis of phytochemicals and elucidation of the mechanism of action of the seed extracts (inhibition of the tumorigenesis or angiogenesis?) under a recently proposed comprehensive ethical framework for clinical research (44).

\section{Acknowledgments}

This work was supported by The University of Missouri Kansas City New Faculty Start up package. The authors are indebted to Covance Laboratories, Inc. (Madison, WI) for timely and accurate analysis of the seeds phytochemicals.

\section{REFERENCES}

1) WHO. 2007. Fifty-seventh session of Regional Committee adopts five Resolutions and a Declaration on Traditional Medicine. AFRO News (A Publication of WHO Regional Office for Africa) 8: 1-4.

2) Vermeer DE, Ferrell RE. 1985. Nigerian geophagical clay: a traditional antidiarrheal pharmaceutical. Science 227: 634-636.

3) Plomelli D, Pollio A. 1994. Medicinal plants. Nature 371: 9.

4) Vandebroek I, Calewaert JB, De jonckheere S, Sanca S, Semo L, Van Damme P, Van Puyvelde L, De Kimpe N. 2004. Use of medicinal plants and pharmaceuticals by indigenous communities in the Bolivian Andes and
Amazon. Bull World Health Organ 82: 243-250.

5) Vogel G. 2000. African research. Traditional and modern medicine merge to save lives. Science 290: 432.

6) Normile D. 2007. Indonesia taps village wisdom to fight bird flu-Participatory epidemiology is Indonesia's first step on a long road to controlling avian influenza. Science 315: 30-33.

7) Bolognesi N. 2006. AIDS in Africa-A question of trust. Nature 443: 626-627.

8) Watson J. 2005. Traditional healers fight for recognition in South Africa's AIDS crisis. Nat Med 11: 6.

9) Gordeuk V, Mukiibi J, Hasstedt SJ, Samowitz W, Edwards CQ, West G, Ndambire S, Emmanual J, Nkanza N, Chapanduka Z, Randall M, Boone P, Romano P, Martell RW, Yamashita T, Effler P, Brittenham G. 1992. Iron overload in Africa-Interaction between a gene and dietary iron content. N Engl J Med 326: 95-100.

10) Youan BBC, Coulibaly S, Miezan TB, Doua F, Bamba M. 1997. In vivo evaluation of sixteen plant extracts on mice inoculated with Trypanosoma brucei gambiense. Bull World Health Organ 75: 343-348.

11) Kavimani S, Manisenthilkumar KT, Ilango R, Krishnamoorthy G. 1999. Effect of the methanolic extract of Glinus lotoides on Dalton's ascitic lymphoma. Biol Pharm Bull 22: 1251-1252.

12) Pankhurst R. 1965. An historical examination of traditional Ethiopian medicine and surgery. Ethiop Med J 3: 157-172.

13) Djote M. 1978. Taenicidal activity of Glinus lotoides (Aizoaceae). J Eth Pharma Assoc 3: 9-11.

14) Endale A, Kassa M, Gebre-Mariam T. 1998. In vivo anthelminthic activity of the extract of the seeds of Glinus lotoides in albino mice infested with Hymenolepis nana worms. Ethiop Pharm J 16: 34-41.

15) Biswas T, Gupta M, Achari B, Pal BC. 2005. Hopanetype saponins from Glinus lotoides Linn. Phytochemistry 66: $621-626$.

16) Endale A, Wray V, Murillo R, Schmidt PC, Merfort I. 2005. Hopane-type saponins from the seeds of Glinus lotoides. J Nat Prod 68: 443-446.

17) Kune G, Watson L. 2006. Colorectal cancer protective effects and the dietary micronutrients folate, methionine, vitamins B6, B12, C, E, selenium, and lycopene. Nutr Cancer 56: 11-21.

18) Ferguson PJ, Kurowska EM, Freeman DJ, Chambers AF, Koropatnick J. 2006. In vivo inhibition of growth of human tumor lines by flavonoid fractions from cranberry extract. Nutr Cancer 56: 86-94.

19) Waladkhani AR, Clemens MR. 1998. Effect of dietary phytochemicals on cancer development. Int J Mol Med 1: $747-753$.

20) Surh YJ. 2003. Cancer chemoprevention with dietary phytochemicals. Nat Rev Cancer 3: 768-780.

21) Sarkar FH, Li YW. 2004. Cell signaling pathways altered by natural chemopreventive agents. Mutat Res $\mathbf{5 5 5}$ : 53-64.

22) Morse MA, Stoner GD. 1993. Cancer chemoprevention -Principles and prospects. Carcinogenesis 14: 17371746.

23) Cort WM, Vicente TS, Waysek EH, Williams BD. 1983. Vitamin E content of feedstuffs determined by high-performance liquid chromatographic fluorescence. J Agric Food Chem 31: 1330-1333.

24) AOAC. 2007. Official Methods of Analysis of AOAC International, 18th ed. Gaithersburg, MD. 
25) Wu XL, Gu LW, Holden J, Haytowitz DB, Gebhardt SE, Beecher G, Prior RL. 2004. Development of a database for total antioxidant capacity in foods-A preliminary study. J Food Compost Anal 17: 407-422.

26) Srivastava JK, Gupta S. 2007. Antiproliferative and apoptotic effects of chamomile extract in various human cancer cells. J Agric Food Chem 55: 9470-9478.

27) Shukla S, Gupta S. 2005. Dietary agents in the chemoprevention of prostate cancer. Nutr Cancer 53: 18-32.

28) Greenwald P, Clifford CK, Milner JA. 2001. Diet and cancer prevention. Eur J Cancer 37: 948-965.

29) Fazzio A, Marilley D, Azzi A. 1997. The effect of alphatocopherol and beta-tocopherol on proliferation, protein kinase $\mathrm{C}$ activity and gene expression in different cell lines. Biochem Mol Biol Int 41: 93-101.

30) Crott JW, Liu Z, Keyes MK, Choi SW, Jang H, Moyer MP, Mason JB. 2007. Moderate folate depletion modulates the expression of selected genes involved in cell cycle, intracellular signaling and folate uptake in human colonic epithelial cell lines. J Nutr Biochem 19: 328335.

31) Marshall JR. 2008. Prevention of colorectal cancer: Diet, chemoprevention, and lifestyle. Gastroenterol Clin North Am 37: 73-82.

32) Lippman SM, Goodman PJ, Klein EA, Parnes HL, Thompson IM, Kristal AR, Santella RM, Probstfield JL, Moinpour CM, Albanes D, Taylor PR, Minasian LM, Hoque A, Thomas SM, Crowley JJ, Gaziano JM, Stanford JL, Cook ED, Fleshner NE, Lieber MM, Walther PJ, Khuri FR, Karp DD, Schwartz GG, Ford LG, Coltman CA. 2005. Designing the Selenium and Vitamin E Cancer Prevention Trial (SELECT). J Natl Cancer Inst 97: 94102.

33) Lu JX, Jiang C. 2005. Selenium and cancer chemoprevention: Hypotheses integrating the actions of selenoproteins and selenium metabolites in epithelial and non-epithelial target cells. Antioxid Redox Signal 7: 1715-1727.

34) Rikiishi H. 2007. Apoptotic cellular events for selenium compounds involved in cancer prevention. J Bioenerg
Biomembr 39: 91-98.

35) Suzuki R, Yasui Y, Kohno H, Miyamoto S, Hosokawa M, Miyashita K, Tanaka T. 2006. Catalpa seed oil rich in $9 \mathrm{t}, 11 \mathrm{t}, 13 \mathrm{c}$-conjugated linolenic acid suppresses the development of colonic aberrant crypt foci induced by azoxymethane in rats. Oncol Rep 16: 989-996.

36) Culp BR, Titus BG, Lands WEM. 1979. Inhibition of prostaglandin biosynthesis by eicosapentaenoic acid. Prostaglandins Med 3: 269-278.

37) Mauritz I, Westermayer S, Marian B, Erlach N, Grusch M, Holzmann K. 2006. Prostaglandin E-2 stimulates progression-related gene expression in early colorectal adenoma cells. Br J Cancer 94: 1718-1725.

38) Stoner GD, Chen T, Kresty LA, Aziz RM, Reinemann T, Nines R. 2006. Protection against esophageal cancer in rodents with lyophilized berries: Potential mechanisms. Nutr Cancer 54: 33-46.

39) Mates JM, Sanchez-Jimenez FM. 2000. Role of reactive oxygen species in apoptosis: Implications for cancer therapy. Int J Biochem Cell Biol 32: 157-170.

40) Endale A, Kammerer B, Gebre-Mariam T, Schmidt PC. 2005. Quantitative determination of the group of flavonoids and saponins from the extracts of the seeds of Glinus lotoides and tablet formulation thereof by highperformance liquid chromatography. J Chromatogr A 1083: $32-41$.

41) Takagaki N, Sowa Y, Oki T, Nakanishi R, Yogosawa S, Sakai T. 2005. Apigenin induces cell cycle arrest and p21/WAF1 expression in a p53-independent pathway. Int J Oncol 26: 185-189.

42) McKay DL, Blumberg JB. 2007. A review of the bioactivity of South African herbal teas: Rooibos (Aspalathus linearis) and Honeybush (Cyclopia intermedia). Phytother Res 21: 1-16.

43) Anwar F, Latif S, Ashraf M, Gilani AH. 2007. Moringa oleifera: A food plant with multiple medicinal uses. Phytother Res 21: 17-25.

44) Tilburt JC, Kaptchuk TJ. 2008. Herbal medicine research and global health: an ethical analysis. Bull World Health Organ 86: 594-599. 